\title{
The Development of Teaching Material Speaking 2 Based on Communicative Approach
}

\author{
Darmaliana $^{1, *}$, Risnawati ${ }^{2}$, Risa $^{3}$, Sri Endah Kusmartini ${ }^{4}$ \\ ${ }^{1-4}$ English Department, State Polytechnic of Sriwijaya, Palembang, Indonesia \\ "Corresponding author Email: annapolsri@yahoo.com
}

\begin{abstract}
The aim of this research is to develop speaking 2 teaching materials based on the communicative approach. This study was carried out at the English Department State Polytechnic of Sriwijaya, the sample of this study are semesters 2,4,6 and English lecturers with a total 100 respondents, in the acedemic year of 2018/2019. This study applied the Small Scale Project of R \& D proposed by Gall, Borg, and Gall (2003) which includes: (1) Research and Information and Collecting. (2) Planning; (3) Initial product development (Develop preliminary form of product); (4) Limited trial (Main Product revision), and (5) Field test (Main Field Testing). The Small Scale project of Research and Development is carried out. The development of the Speaking 2 teaching material based on the communicative approach guided by Nation (2009) which reveals the characteristics of the communicative approach are ; meaning is the most important, conversation must be centered around communicative functions and not memorized normally, contextualization is the first premise, language learning means learning to communicate, effective communication is recommended.
\end{abstract}

Keywords: speaking 2, communicative based approach

\section{1.. INTRODUCTION}

The era of advancing science and technology is increasing rapidly, the more open opportunities to communicate internationally and the free market that is immediately implemented demands that the Indonesian people have competitive competence in all fields. Indonesia can no longer rely solely on natural resources and physical ability to achieve the welfare of its people, but must rely more on professional human resources. One of the requirements to achieve this is the ability to speak English, especially to communicate verbally.

English plays an important role, the use of English is increasingly felt urgent to be able to keep up with developments. Developments in the field of technology and science and information, One of the missions of the English Language Department, Sriwijaya State Polytechnic is to produce competent and professional graduates in communicating using English in the hospitality industry (Sriwijaya's Polytechnic Student Guideline) [1]. The mission reinforces that students of the English Language Department after completing their studies at the Sriwijaya State Polytechnic must have English speaking skills. Based on the vision in the Sriwijaya State Polytechnic Language Department, a continuous development effort is needed from several supporting components of Speaking 2 learning activities. Learning activities are complex activities because they involve many components. One of the most important components to achieving these goals is teaching materials. To diagnose the problems faced by students in speaking English, the research team conducted a prior study in 2019 for English Department students to find out their problems in learning in speaking subjects, especially speaking 2 courses at the English department, State Polytechnic of Sriwijaya Palembang. The problems faced by students in communicating English are as follows (1) Lack of selfconfidence when conveying ideas in front of friends, (2) lack of vocabulary mastery. (3) The tendency to use mother tongue still dominates students during the learning process. There are several factors that cause these problems, (1) Learning strategies for speaking subjects are less attractive so students are less motivated to speak English (2) Teaching material. Of the several factors that cause these problems, the research team assumed that the main factor causing the problem in speaking in English was teaching material. Teaching material is one aspect that must be present in a learning process because teaching materials are a source of lecturers and students in carrying out a learning process. Teaching materials made should be adapted to the characteristics of students and the learning objectives in the class so that the learning process can run well and the measured abilities can be achieved.

There are several similar studies that are related to our research. First, research conducted by Angga Taufan Dayu, Hidayatullah, and Raudhatul Haura [2], entitled Development of English Language Teaching Materials in Mechanical Engineering at the Islamic University of Kalimantan. The results showed that the development of 
ESP teaching materials should be directed at disciplines and scientific fields. Therefore, the substance and content of ESP is related to themes and topics in certain fields of study, types of work or certain activities. ESP must also be centered on the form of language that is appropriate to the activities and fields of science or work. Linguistically, the smallest form of language can be comprehensively analyzed through phonetics and phonology where the field of study is working on matters relating to sound and phonemes. At the level of vocabulary with all the categories and structure of its formation analyzed in the field of morphology studies, then at the level of sentences that include phrases and clauses studied in depth through the field of syntactic science. In addition, receptive skills such as listening and reading and productive skills such as speaking and writing are an integral part of ESP. Second, research conducted by Risa, Sri Endah, Risnawati and Sri Endah [3] entitled "Development of the Teaching Modules of Speaking 1 into the Textbook Speaking 1". This study applied a research and development (R \& D) method developed by Gall and Gall [4]. The results of this study indicate that the various themes, supporting aspects, exercises and strategies in each chapter provide an opportunity for students to practice improving skills in better, effective and professional speaking competence.

There are differences and similarities between previous research and recent research. The similarities between previous and present research are as follows (1). Research conducted by Risa, Sri Endah, Risnawati and Sri Endah, and Angga Taufan Dayu, Hidayatullah, and Raudhatul Haura in 2017 focused on English subjects (2) The two studies applied research and development (R\&D). While the differences in previous research with research research are as follows: (1) Research conducted by Angga Taufan Dayu, Hidayatullah, and Raudhatul Haura in 2017, developed English language material that is suitable for the needs of engineering department students while the recent research aims to produce speaking 2 materials based on communicative approaches.

In this study, the research team developed speaking 2 teaching material based on a communicative approach. The communicative approach is an approach based on the idea that the ability to use language in communication is a goal that must be achieved in language learning. The concept of a communicative approach is how the language is applied in communication so that it can integrate four language skills (listening, speaking, reading and writing). According to Hammer [4] Integrating four language skills is very important to improve knowledge and proficiency in speaking English (Harmer).From the background of the problem, the formulation of the problems in this study are:

1. How to analyze students' needs in Speaking 2, Semester 2 of the English Department, State Polytechnic of Sriwijaya Palembang?

2. What materials or topics support the speaking 2 learning process, Semester 2 of the English Department, State Polytechnic of Sriwijaya Palembang?

3. How to develop Speaking 2 teaching materials based on the communicative approach, Semester 2 of the
English Department, State Polytechnic of Sriwijaya Palembang?

\section{LITERATURE REVIEW}

\subsection{The concepts of Speaking}

Speaking in general can be interpreted as conveying one's intentions (ideas, thoughts, contents) to others by using spoken language so that the intentions can be understood. However, speaking skills are difficult to develop if not trained continuously and can be done with colleagues in the class, language lecturers English, English teachers, or other teachers who can speak English. The aim is to facilitate speaking skills, enrich vocabulary usage, improve language structure, perfect vocabulary words, English sentences, and train hearing so that it is easy to capture messages from the other person. If the learner wants to speak English, then he must be able to pronounce vocabulary, accuracy, intonation well too.

\subsection{The Concepts of Development}

The word development shows that an activity produces a new tool or method, during which the assessment and improvement of the tool or method is continued (Sutopo, Hendayat \& Westy Soemanto), [5] . If after experiencing improvements, the tool or method is deemed sufficiently solid to be used onward, then the development activity ends. In line with the statement of Kemp in Trianto [6], the development of devices is a continuum level.Each development step is directly related to the revision activity. Revisions are intended to perfect the tools or methods according to purpose Whereas according to Seels \& Richey [7], development is the process of translating the design specifications into physical form. Development is the process of translating predetermined design specifications into physical forms that can be used in learning. They also explain that development is the process of writing and making or producing learning materials. Efforts to develop learning materials must be complemented by supporting theoretical studies.

Based on some of the opinions above, development can be defined as the process of producing a design or product into a physical form through gradual changes in the form of revision activities by utilizing the principles and theories of science that have been proven to be true.

\subsection{Teaching Materials}

According to Pannen [8] Teaching Materials are learning materials that are systematically arranged, which are used by lecturers and students in the learning process . Teaching materials are important part of the learning process. As 
Mulyasa [9] suggests that teaching material is one part of teaching resources that can be interpreted something that contains a message of learning, both special and general in nature that can be used for the benefit of learning. This means that teaching materials must contain learning messages that are important in supporting learning.

Based on the study above, the understanding of teaching materials is all forms of material (both information, tools, and text) that contain learning material, methods, boundaries, and ways of evaluating systematically and interestingly according to the curriculum used in order to achieve the objectives expected, namely achieving the competencies that must be mastered by students.

\subsection{The Concept of Communicative Approach}

The communicative approach is an approach based on the idea that the ability to use language in communication is a goal that must be achieved in language learning. Communicative competencies are the interrelationships between grammatical competencies or knowledge of language rules with sociolinguistic competencies or rules about the use of languages that are in accordance with community culture. Communicative competence should be distinguished from communicative performance because communicative performance refers to the realization of linguistic competencies and their interactions in actual production with an understanding of speeches. Nation [10] revealed the characteristics of a communicative approach

\section{RESEARCH METHODOLOGY}

This research was designed using research and development ( $\mathrm{R} \& \mathrm{D})$. Research and development is a process or steps to develop a new product or perfect an existing product. According to Gay [11] development research is an attempt to develop an effective product for school use, and not to test theory. Rita [12] defines development research as a systematic assessment of design, development and evaluation of learning programs, processes and products that must meet the criteria of validity, practicality, and effectiveness. While Plomp[13] added the criteria "can show added value" in addition to the three criteria. This study applied the Small Scale Project of R \& D proposed by Gall, Borg, and Gall (2003) which includes: (1) Research and information collection (2) Planning; (3) Initial product development (Develop preliminary form of product); (4) Limited trial (Main Product revision), and (5) Field test (Main Field Testing). The Small Scale project of Research and Development is carried out solely because of limited time and costs. This study was carried out in the English Department State Polytechnic of Sriwijaya, the sample of this study are semesters
2,4,6 and English lecturers with a total 100 respondents, in the acedemic year of 2018/2019.

\subsection{Techniques for collecting the data}

Data collection techniques used in the research via questionnaires and interviews. Questionnaires are used to know the needs of students and lecturers. The questionnaire contained 20 speaking skill focus. Students are recommended to choose 10 by giving a sign $(\mathrm{X})$ of 20 speaking skills focus which they think is very useful in the learning process and work field. Interview is used to support the questioners spreaded. After the teaching materials have been designed, the writer distributed the questioners to users and lecturers who teach speaking 2, in order to know to evaluate the suitability of topics with interests, the needs of students in learning in the Speaking 2 courses that had been designed, evaluating whether or not the exercise is in accordance with the topic being taught and whether or not the activities have described reflect communicative-based learning activities.

\subsection{Technique for analyzing the data}

The data analysis technique used in this development research is the analysis of qualitative descriptive data used to process instruments. Analysis of qualitative descriptive data to evaluate the results of questionnaires was carried out with the steps taken including: (1) the researcher collected the analyzed data; (2) the researcher prepares the data to be analyzed; (3) the researcher reread all data carefully; (4) The researcher calculated the percentage of 10 speaking skill focus chosen by students (5) 10 speaking skill focus would be the foundation of researchers to develop speaking teaching material 2 based on communicative approach (6) Researchers designed expressions, exercises on each selected topic by students. then presents descriptions and themes to facilitate the process of analysis and interpretation of data; (7) the researcher analyzes and interprets the data carried out in an integrated manner.

To analyze the results of interviews with lecturers and students, researchers conducted the following steps (1) reviewing the input from students and lecturers (2) narrating the interview data qualitatively to support the 10 speaking skill focus students had chosen.

\section{FINDINGS AND DISCUSSION}

\subsection{Findings}

In the first stage, the research team conducted document analysis including evaluation of teaching modules, as well 
as conducting interviews. The documents analyzed are speaking 2 teaching modules which have been used as teaching materials for students of the Palembang Sriwijaya State Polytechnic English Department. After analyzing it is known that the previous teaching material was not based on the needs of students but only based on the author's assumptions of the teaching material used. Furthermore, the new teaching material is compilation, meaning collections of books are put together into one. And the materials and exercises do not yet describe communicative based learning.

Next the research team conducted a needs analysis. The researcher designed a questionnaire to find out the needs of students in designing speaking 2 teaching material based on a communicative approach, the interview instrument was used to support the questionnaire to be filled in the form of their suggestions whether there was additional material from the topic offered. There are 20 speaking skill focus. Students are recommended to choose 10 of the 20 speaking skills focus which they think are very useful in the learning process and the work field. Designing Speaking skills focus refers to: Syllabus and description of Speaking 2 courses, the mission of the English Language Department is to produce graduates who are competent and professional in communicating using English in the hospitality industry, semester courses 1,2,3 related to hospitality and Industry: Guiding Technique, professional ethics, tourism marketing, tourism destination and attraction, hotel management, public relations, hotel marketing, customer service psychology.

Table 1 The Draft Frame work of Speaking 2 Communicative Based Approach materials before Revision

\begin{tabular}{|c|c|}
\hline Materials & Topics given to the students \\
\hline $\begin{array}{l}\text { Learning } \\
\text { objectives }\end{array}$ & The competences gained by students after learning \\
\hline Activities & $\begin{array}{ll}\text { - } & \text { Presentation } \\
\text { - } & \text { Discussion } \\
\text { - } & \text { Questions and answers } \\
\text { - } & \text { Role Play } \\
\text { - } & \text { Peer working } \\
\text { - } & \text { Group Work Activities } \\
\end{array}$ \\
\hline Exercises & $\begin{array}{l}\text { 1. Matching thepictureswithwordsbelow . } \\
\text { 2. Completing } \\
\text { thefollowingconversationwiththemissing } \\
\text { words. } \\
\text { 3. Joina partner. } \\
\text { 4. Pickoneofthefollowingsituationsandper } \\
\text { formitinfrontoftheclass: }\end{array}$ \\
\hline
\end{tabular}

The research team then distributed questionnaires to students and lecturers and conducted interviews to support the questionnaire that had been filled in the form of their suggestions whether there was additional material from the topic offered. 10 speaking skills of the most chosen students were the foundation of researchers to develop speaking 2 teaching materials based on communicative approaches. After the questionnaire was distributed and analyzed, then the following percentage of students' choice of 20 speaking skill focus. The following are the ten materials chosen by students and lecturers:

1. Customer Service

2. Asking and giving information on the phone

3. Expressing apoligies and complaint

4. Asking and giving information about tourism

5. Talking about tourist attraction

6. Talking about attraction in my home town

7. Describing Tourists attraction

8. Comparing different hotels

9. Checking guests in/out

10. Offering HotelServicesandFacilities

The second stage of activity is Planning. At the design stage the research team designed the arrangement of teaching materials with design shown in Table 1.

The third stage is development; initial product development in the form of speaking teaching design material 2 based on a communicative approach. Based on the questionnaire that spreads the following material that supports the Speaking 2 learning process, Semester 2 of the English Language Department, State Polytechnic of Sriwjaya Palembang. The communicative approach is an approach based on the idea that the ability to use language in communication is a goal that must be achieved in language learning as stated by Ro (14). The methods of communicative language learning are based on learning theory that refers to two principles, namely (1) the principle of communication, activities that involve real communication capable of developing the learning process, (2) the principle of tasks, activities where the language is used for carrying out tasks that can significantly develop the learning process. Based on these principles, language learning material should be applied through game methods, simulations, role playing, and partner communication. With the communicative approach it is expected that the goal of education is to be able to develop potential, have skills that are useful for themselves, society, nation and state can be achieved well and by increasing trust between students and educators is the first step to establish communicative communication. In the learning process also integrates four language skills (listening, speaking, writing and reading)

The fourth stage is limited trials. At this stage, the research team gave questionnaires to book users and experts in this case the lecturers who taught speaking subjects. 2 objectives rather than limited trials were to evaluate the suitability of the topic with interest, the needs of students in learning in Speaking courses. with the topic being taught and evaluating whether the activities have described communicative-based learning activities. After the questionnaire was analyzed, the following results were obtained.

In their opinion the topic fits their needs and interests because in the learning process several topics are very often applied in the learning process. Besides that the material developed is very useful when they enter the workforce. Like the topic of customer service, asking and giving information on the phone, expressing apologies and complaints is very important when they work as a receptionist or front desk, supervisor or other work. And 
some other topics are very useful when they are engaged in hospitality and tourism such as topics asking and giving information about tourism, talking about tourism and attraction, comparing hotels, checking guests in / out and comparing different hotels. Their suggestions, you should add examples of conversations or dialects related to the material being taught, and given the exercises related to the conversation. Afterconversation and practice it is best to learn about the phrases used in daily life. Because speaking 2 is based on communicative learning, it is better to integrate 4 language skills (listening, speaking, reading, writing) in assignments given to students, students can also access the internet to do assignments given by lecturers. Overall teaching material 2 developed has illustrated communicative language learning.

The fifth stage is the revision of the results of limited trials. At this stage, revisions are made to the input given by the lecturer in speaking 2 courses. Revisions are carried out according to the advice given. Table 2 is the format of teaching material after being given input.

Table 2 The Framework of Teaching Materials of Speaking 2 Communicative Based Approach after revision

\begin{tabular}{|c|c|}
\hline $\begin{array}{l}\text { Material } \\
\text { / topic of } \\
\text { learning }\end{array}$ & Customer Service \\
\hline $\begin{array}{l}\text { Objectiv } \\
\text { es }\end{array}$ & $\begin{array}{l}\text { After completing this lesson, the students } \\
\text { will be able to : } \\
\text { - greet customer and help him or } \\
\text { her using certain expressions } \\
\text { politely. } \\
\text { - Use new vocabulary related to the } \\
\text { topic }\end{array}$ \\
\hline $\begin{array}{l}\text { Pre } \\
\text { Speaking } \\
\text { Activitie } \\
\text { S }\end{array}$ & $\begin{array}{l}\text { What kinds of things can you order from } \\
\text { room service at a hotel? What types of } \\
\text { hotels offer such services? }\end{array}$ \\
\hline $\begin{array}{l}\text { Example } \\
\mathrm{s} \text { of } \\
\text { conversa } \\
\text { tions } \\
\text { relating } \\
\text { to the } \\
\text { topic of } \\
\text { learning }\end{array}$ & $\begin{array}{l}\text { Examples of conversations relating to the } \\
\text { topic of learning }\end{array}$ \\
\hline $\begin{array}{l}\text { Question } \\
\text { s related } \\
\text { to } \\
\text { dialoque } \\
\text { s }\end{array}$ & Questions related to dialoques \\
\hline $\begin{array}{l}\text { Phrases } \\
\text { related } \\
\text { to the } \\
\text { topic }\end{array}$ & Phrases related to the topic \\
\hline $\begin{array}{l}\text { Exercise } \\
\text { s related } \\
\text { to }\end{array}$ & $\begin{array}{ll}\text { 1. } & \text { Matching } \\
\text { thepictureswithwordsbelow . } \\
\text { 2. }\end{array}$ \\
\hline
\end{tabular}

\begin{tabular}{|l|ll|}
\hline $\begin{array}{l}\text { Material } \\
\text { topic of } \\
\text { learning }\end{array}$ & & \multicolumn{1}{c|}{ Customer Service } \\
\hline $\begin{array}{l}\text { learning } \\
\text { material }\end{array}$ & $\begin{array}{l}\text { thefollowingconversationwiththem } \\
\text { issingwords. } \\
\end{array}$ & $\begin{array}{l}\text { Joina partner. } \\
\text { 4. }\end{array}$ \\
& & $\begin{array}{l}\text { Pickoneofthefollowingsituationsa } \\
\text { ndperformitinfrontoftheclass: }\end{array}$ \\
\hline $\begin{array}{l}\text { Commun } \\
\text { icative }\end{array}$ & $\bullet$ & Presentation \\
based & $\bullet$ & Discussion \\
learning & $\bullet$ & Questions and answers \\
strategie & $\bullet$ & Role Play \\
s related & $\bullet$ & Peer working \\
to & $\bullet$ & Group Work Activities \\
learning & $\bullet$ & On line investigations \\
topics. & & \\
\hline
\end{tabular}

In the revision of teaching material, the research team added examples of conversations or dialects related to the material being taught, and given training related to the conversation. Next add the expressions used in daily life that are related to the topic. Adding training in line investigation with the assumption that speaking 2 communicative based learning should integrate 4 language skills (listening, speaking, reading, writing) in assignments given to students, students can also access the internet to do assignments given by lecturers.

\section{2. Discussion}

Teaching materials should be designed and written in accordance with the learning rules, which are adjusted to the learning material, arranged based on learning needs, displaying competencies to be mastered, accompanied by evaluation designs and interesting to learn by students. From the needs analysis, 10 materials were found which according to them were very important in the learning process and the world of work. In the learning process, it will be easier for students to use expressions in English in subjects related to Hospitality and Industry which will indirectly increase students' interest and learning achievement. In the work field, the materials contained in Speaking 2 teaching materials help them in using English in the work climate. The ten materials / topics and expressions used according to their needs. In addition, ten topics that have been developed are guided by; Syllabus and description of Speaking 2 courses; The mission of the English Language Department is to produce graduates who are competent and professional in communicating using English in the hospitality industry; 1,2,3 semester courses related to hospitality and Industry: Guiding Technique, professional ethics, tourism marketing, tourism destination and attraction, hotel management, public relations, hotel marketing, customer service psychology. The process captures the needs of students in line with what said Pannen (1999) that the interests of learning can not be separated from the goals to be achieved in the learning 
process. Through this teaching material students are directed to the learning objectives. In other words the goals to be achieved by students are formed by teaching materials.

The development of the Speaking 2 teaching material based on the communicative approach guided by Nation (2009) which reveals the characteristics of the communicative approach are (1) meaning is the most important, (2) conversation must be centered around communicative functions and not memorized normally, (3) contextualization is the first premise, (4) language learning means learning to communicate, (5) effective communication is recommended, (6) rehearsal or drill exercises are allowed, but not burdensome, (7) utterances that can be understood prioritized, (8) each tool for students (9) all efforts to communicate can be encouraged from the start, (10) the use of language wisely is acceptable if it is appropriate, (11) translation is used if needed by students, (12) reading and writing can be started from the beginning, (13) the language system is learned through communication activities, (14) communicative communication is the goal, (15) linguistic variation is the core concept in material and methodology, (16) the sequence is determined based on consideration of content, function, or meaning to strengthen interest in learning, (17) the teacher encourages students to work together using that language, (18) language created by students through trying and try, (19) fluent and fluent language is the main goal, accuracy is assessed in context not in abstractity, (20) students are expected to interact with other people through groups or partners, oral and written, (21) teachers cannot predict what language that will be used by students, and (22) intrinsic motivation will arise through interest in things that are communicated. Speaking teaching material 2 developed by researchers has traced the characteristics written by Nation (2009). Emerging communicative activities.

\section{CONCLUSIONS}

Disseminate questionnaire to students and lecturers guided by Syllabus and description of Speaking 2 courses, Mission of the English Language Department which is to produce graduates who are competent and professional in communicating using English in the hospitality industry; 1,2,3 semester courses related to hospitality and Industry: Guiding Technique, professional ethics, tourism marketing, tourism destination and attraction, hotel management, public relations, hotel marketing, customer service psychology. From the 20 speaking skills focus offered, students and lecturers choose 10

speaking skills focus which they think is very important in supporting work field. In their opinion the topic fits their needs and interests because in the learning process several topics are very often applied in the learning process. Besides that the material developed is very useful when they enter the workforce. Like the topic of customer service, asking and giving information on the phone, expressing apologies and complaints is very important when they work as a receptionist or front desk, supervisor or other work. And some other topics are very useful when they are engaged in hospitality and tourism

To optimize the use of speaking 2 teaching materials, the researcher suggests the following: Before using speaking 2 teaching material, the lecturer should look at the instructions in the instruction manual so that the process of using the learning is in accordance with the existing guidelines. Lecturers should give assignments to students to study textbooks at home, so that when the lecture takes place it is expected that students can be more active. The completeness of the accompanying speaking 2 teaching material needs to be developed, such as question sheets, answer sheets, worksheets / assignments, assessment sheets, and student progress sheets to assist lecturers in learning activities.

\section{REFERENCES}

[1] Buku Pedoman Mahasiswa. 2018. Politeknik Negeri Sriwijaya.

[2] Angga Taufan Dayu. 2017. Hidayatullah, dan Raudhatul Haura. Pengembangan Materi Ajar Bahasa Inggris Teknik Mesin Universitas Islam Kalimantan Mab. Prosiding Hasil Penelitian Dosen.

[3] Risa, et all. 2018. Development of the Teaching Modules of Speaking 1 into the textbook Speaking 1. Holistics Journal, Volume 10, Number 20 December 2018.

[4] Gall, M.D., Borg, W.R. \& Gall, J.P. 2003. Educational Research. An Introduction (seventh edition). United States of America: Peaeson Education Inc.

[5] Harmer Jeremy. 2009. The Practice of English Language Teaching. Longman Handbooks for Language Teachers. Longman: London and New York.

[6] Sutopo, Hendayat \& Westy Soemanto.1993. Pembinaan dan Pengembangan Kurikulum Sebagai Substansi Problem Administrasi Pendidikan. Jakarta: Bumi Aksara.

[7] Trianto. 2007. Model-Model Pembelajaran Inovatif Berorientasi Konstruktivistik. Jakarta: Prestasi Puastaka.

[8] Sells, Barbara B \& Richey. 1994. .Intructional Technology: The Definition and Domains of the Field. Bloomington: Association for Educational Communications and Technology. 
[9] Pannen, P. 1996. Mengajar di Perguruan Tinggi, Buku Empat, bagian "Pengembangan Bahan Ajar”. Jakarta; PAU-PPAI, Universitas Terbuka.

[10] Mulyasa E. 2006. Kurikulum Berbasis Kompetensi. Bandung: PT Remaja Rosdakarya

[11] Nation, I.S.P. 2009. Teaching ES/EFL Reading and Writing. Routledge. New York, NY

[12] Gay, L.R. 1991. Educational Evaluation and Measurement: Com-petencies for Analysis and Application.Second edition. New York: Macmillan Publishing Company.

[13] Rita. 2009. Developmental Research: Studies of Instructional Design and Development.

[14] Plomp, Tj. 1993. Educational Design: Introduction. From Tjeerd Plomp (eds). Educational \&Training System Design: Introduction. Design of Education and Training (inDutch).Utrecht (the Netherlands): Lemma. Netherland. Faculty of Educational Science andTechnology, University of Twente

[15] Kellen Ro. 1998. Effective Teaching Strategies Lessons from Research and Practice. South Melbourne, Vic: Thomson Social Science Press. 